\title{
Ocean mediation of tropospheric response to reflecting and absorbing aerosols
}

\author{
Y. Xu ${ }^{1}$ and S.-P. Xie ${ }^{2}$ \\ ${ }^{1}$ National Center for Atmospheric Research, Boulder, CO 80303, USA \\ ${ }^{2}$ Scripps Institution of Oceanography, University of California, San Diego, La Jolla, CA 92093, USA \\ Correspondence to: Y. Xu (yangyang@ucar.edu)
}

Received: 24 January 2015 - Published in Atmos. Chem. Phys. Discuss.: 25 February 2015

Revised: 23 April 2015 - Accepted: 5 May 2015 - Published: 27 May 2015

\begin{abstract}
Radiative forcing by reflecting (e.g., sulfate, $\mathrm{SO}_{4}$ ) and absorbing (e.g., black carbon, BC) aerosols is distinct: the former cools the planet by reducing solar radiation at the top of the atmosphere and the surface, without largely affecting the atmospheric column, while the latter heats the atmosphere directly. Despite the fundamental difference in forcing, here we show that the structure of the tropospheric response is remarkably similar between the two types of aerosols, featuring a deep vertical structure of temperature change (of opposite sign) at the Northern Hemisphere (NH) mid-latitudes. The deep temperature structure is anchored by the slow response of the ocean, as a large meridional sea surface temperature (SST) gradient drives an anomalous interhemispheric Hadley circulation in the tropics and induces atmospheric eddy adjustments at the $\mathrm{NH}$ mid-latitudes. The tropospheric warming in response to projected future decline in reflecting aerosols poses additional threats to the stability of mountain glaciers in the NH. Additionally, robust tropospheric response is unique to aerosol forcing and absent in the $\mathrm{CO}_{2}$ response, which can be exploited for climate change attribution.
\end{abstract}

\section{Introduction}

Greenhouse gas-induced global warming is partially masked (Ramanathan and Feng, 2008) by the accompanying increase in anthropogenic aerosols (Smith et al., 2011). The relative contribution of the aerosol masking effect on global temperature is hard to quantify for the following reasons: (a) some aerosols (e.g., black carbon (BC) and organics) absorb sunlight and heat the planet (Bond et al., 2013) and (b) aerosol microphysical effects on clouds are complex (Rosenfeld et al., 2013). Many ongoing efforts aim to reduce uncertainties in radiative forcing (Xu et al., 2013) and quantify the surface temperature response to aerosols (Levy et al., 2013). The atmospheric circulation response to reflecting aerosols has important effects on the regional climate (e.g., the Indian monsoon; Bollasina et al., 2011) and hydrological cycle (Shindell et al., 2012; Hwang et al., 2013). Much attention has been given to absorbing aerosols for the direct atmospheric heating effect, including BC (Meehl et al., 2008) and dust (Vinoj et al., 2014). It is often argued that, by heating directly the atmosphere, absorbing aerosols can greatly perturb the atmospheric temperature structure, causing changes in stability and circulation (Lau et al., 2006). The atmospheric response, especially that of clouds, is hypothesized to be sensitive to the vertical profile of atmospheric heating (Koch and Del Genio, 2010). Reflecting aerosols, however, are hinted to be less effective in driving large-scale circulation changes (Allen et al., 2012).

While previous studies (e.g., Xie et al., 2013; Ocko et al., 2014) focused on radiative forcing and climate impacts of aerosols on surface temperature and precipitation (Table S1 in the Supplement), few looked at the tropospheric response. Using climate model simulations, we show that the atmospheric responses (temperature and circulation) to reflecting and absorbing aerosols are surprisingly similar in structure (aside from a sign difference). Both responses feature a deep vertical temperature structure at the Northern Hemisphere (NH) mid-latitudes, with a meridional shift in the westerly jet. Such a strong atmospheric temperature response to absorbing aerosols has been commonly linked to direct solar absorption in the atmosphere (Lau et al., 2006). We demon- 
strate, however, that changes in the sea surface temperature (SST) gradient and mid-latitude eddies are instrumental in creating a common deep vertical temperature in response to both types of aerosols, despite the fundamental difference in their forcing structure.

\section{Methods}

\subsection{The global climate model}

CESM1 (Community Earth System Model 1) is a coupled ocean-atmosphere-land-sea-ice model. CESM1 climate projections for the twenty-first century have been documented extensively (Meehl et al., 2013). The anthropogenic forcings in CESM1 include long-lived greenhouse gases (GHGs), as well as tropospheric ozone, stratospheric ozone, sulfate aerosols, and black and primary organic carbon aerosols. The three-mode aerosol scheme (MAM3) provides internally mixed representations of aerosol number concentrations and masses (Liu et al., 2012). Aerosol indirect forcing is included for both liquid and ice phase clouds (Gettelman et al., 2010).

The aerosol emission inventory is from the standard representative concentration pathway as described in Lamarque et al. (2010). However, the present-day emission level of BC is adjusted from the standard model emission inventory to account for the potential model underestimation of $\mathrm{BC}$ atmospheric heating. Our previous analysis (Xu et al., 2013) shows that such a correction improves simulated radiative forcing compared to the direct observations. Without the observational constrains, simulated BC forcing (and associated temperature response) would be lower by about a factor of 2 . In addition to the atmospheric heating, deposition of BC particles onto snow surface with high albedo would reduce surface albedo and contribute to surface warming (Huang et al., 2011). The land model of CESM incorporates the SNICAR (Snow and Ice Aerosol Radiation) module, which represents the effect of aerosol deposition (BC, organic carbon and dust) on surface albedo (Flanner et al., 2007).

Note that in this study we used BC, a strong absorber, to characterize absorbing aerosols that also include dust and organic aerosols. Similarly, we used $\mathrm{SO}_{4}$ to characterize reflecting aerosols, although dust and organic aerosols are also partially reflecting. This approach provided a clearer contrast between these two types of aerosol forcing.

\subsection{Model experiments}

a. Fully coupled model simulations with instantaneous forcing. We used a 394-year, pre-industrial simulation as the control case. Starting from the end of the 319th year, we ran the simulations for 75 years, with the last 60 years of output analyzed. This allows the first 15 years for model spin-up to establish a quasiequilibration with changes in radiative forcing (Long et al., 2014). The forcing is imposed by increasing BC emissions (as a proxy for absorbing aerosols) and $\mathrm{SO}_{2}$ emissions (a precursor of $\mathrm{SO}_{4}$, as a proxy for reflecting aerosols) instantaneously from pre-industrial levels to the present-day level. This methodology is similar to the classical $\mathrm{CO}_{2}$ doubling experiment (Manabe and Wetherald, 1975). The long averaging time (60 years in the perturbed simulation versus 394 years for the preindustrial control simulations) enabled us to dampen the influence of decadal natural variability and to obtain a clear effect due to aerosol perturbation. To increase the signal-to-noise ratio in the $\mathrm{BC}$ case (due to a smaller BC forcing), five ensembles of perturbed simulations were conducted.

b. The twentieth century transient simulations using fully coupled model, with time-evolving sulfate forcing. The details of the simulations can be found in Meehl et al. (2013). The resolution of both atmosphere and ocean models is $1^{\circ}$ by $1^{\circ}$ for the coupled simulations (Experiments a and b) in this study.

c. The atmospheric-only simulations with instantaneous forcing. The model setting and imposed forcing are identical to a., but SST is fixed at a pre-industrial level, with only seasonal variability. The model was also run for 75 years.

d. The SST perturbation experiment. The SST was perturbed according to the zonal mean of the CESM SO 4 Experiment a (Fig. S1 in the Supplement). This corresponds to a temperature profile that varies from $0{ }^{\circ} \mathrm{C}$ at $90^{\circ} \mathrm{S}$ to $-0.5^{\circ} \mathrm{C}$ at the Equator, and then to $-1.2^{\circ} \mathrm{C}$ at $90^{\circ} \mathrm{N}$. The SST perturbation did not include any longitudinally varying pattern, as our focus here was to understand the zonal averaged temperature response. The perturbed model was run for 25 years (with 10 years of daily output for eddy flux analysis). The resolution of the atmospheric model is $2^{\circ}$ by $2^{\circ}$ for the uncoupled simulations (Experiments $\mathrm{c}$ and $\mathrm{d}$ ) in this study.

\section{Tropospheric response linked to SST gradient}

$\mathrm{BC}$ atmospheric radiative forcing is concentrated at $30^{\circ} \mathrm{N}$ and extends well above the boundary layer to the free atmosphere (Fig. 1), a structure determined by atmospheric concentration, and indirectly by emission sources. Intuitively, solar absorption by $\mathrm{BC}$ results in atmospheric warming. Indeed, BC (Fig. 1 upper panels) induces a warming maximum in the $\mathrm{NH}$ mid-latitude troposphere $\left(350 \mathrm{mb}, 30\right.$ to $\left.40^{\circ} \mathrm{N}\right)$ in the coupled ocean-atmosphere model, which dwarfs the upper tropical and Arctic warming. This simple thermodynamic mechanism seems consistent with the fact that the magnitude of BC warming is much larger in the boreal summer (JJA) than in the boreal winter (DJF) (Fig. 2, upper panels), due to solar insolation. 


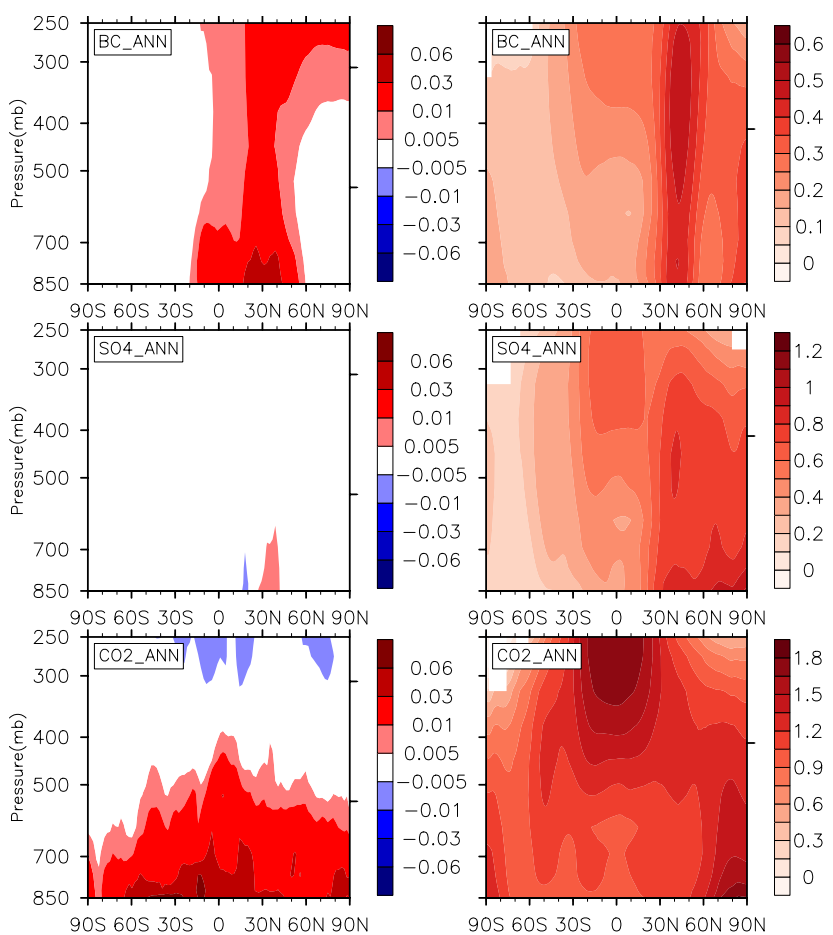

Figure 1. (Left) Heating rate $\left({ }^{\circ} \mathrm{Cday}^{-1}\right)$ due to an increase in $\mathrm{BC}$, $\mathrm{SO}_{4}$ and $\mathrm{CO}_{2}$ atmospheric concentrations. The heating rate is diagnosed by contrasting two sets of 5-year atmospheric-only simulations with pre-industrial and present-day emissions/concentrations, respectively. (Right) Annually averaged atmospheric temperature in response due to the forcing of $\mathrm{BC}, \mathrm{SO}_{4}$ and $\mathrm{CO}_{2}$. The color scale for $\mathrm{SO}_{4}$ is reversed. The magnitude of the color scale is chosen considering the difference in top-of-atmosphere forcing (Table S1).

Interestingly, $\mathrm{SO}_{4}$ also induces a similar enhanced tropospheric cooling at the mid-latitudes (Figs. 1 and 2). For easy comparison, the response is reversed in sign to be positive. The deep atmospheric response is unexpected from the weak, direct atmospheric forcing of reflecting aerosols (Fig. 1, middle left). Also contradictory to the above thermodynamic argument for $\mathrm{BC}$, the temperature response to $\mathrm{SO}_{4}$ is of a similar magnitude in DJF and JJA (Fig. 2). The $\mathrm{CO}_{2}$ response features a structure of amplified upper tropical troposphere warming (maximum at around $300 \mathrm{mb}$ ), which is a robust feature due to thermodynamical adjustment of the tropical atmosphere to maintain a moist adiabatic lapse rate there. The lower tropospheric atmospheric temperature over the Arctic also has a larger response, mostly due to stronger snow albedo feedback.

The climate response may be decomposed into fast and slow components, defined as the atmospheric response without and due to SST change, respectively (Ganguly et al., 2012). The BC temperature response results predominately from the fast component in the summer due to direct atmospheric heating (Fig. 3), but the slow response dominates in the winter. The $\mathrm{SO}_{4}$ fast response, due to the lack of atmo-

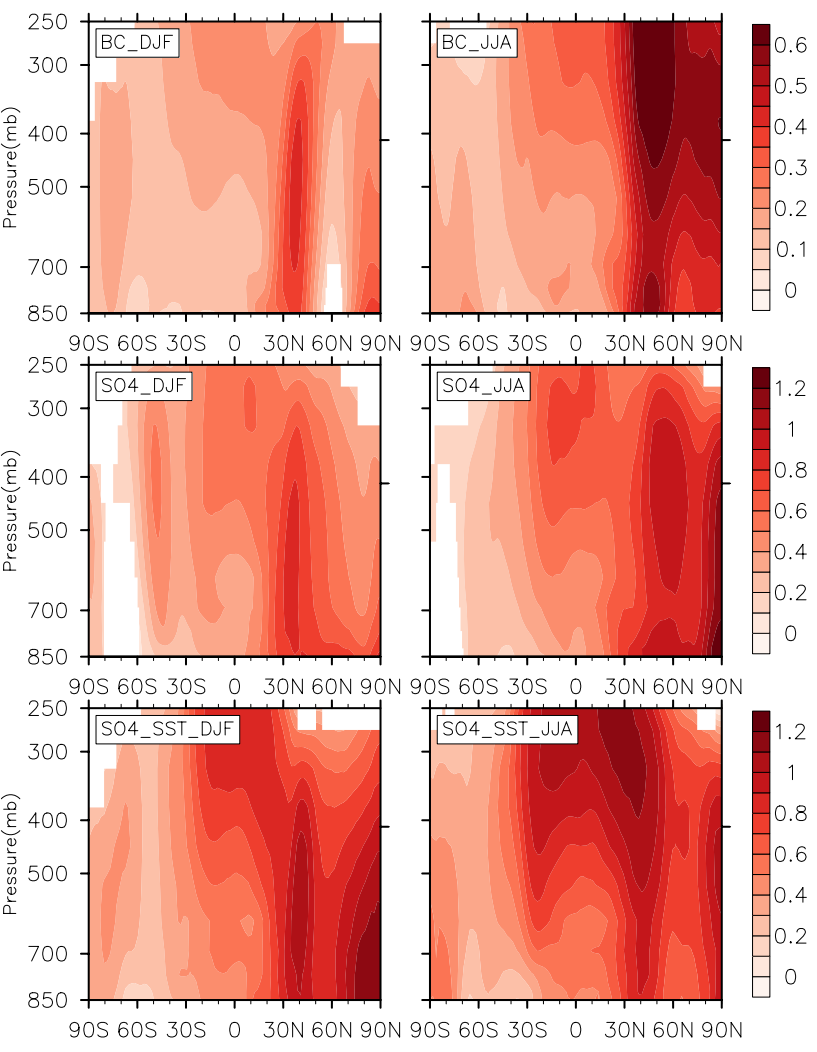

Figure 2. Temperature response $\left({ }^{\circ} \mathrm{C}\right)$ as a function of latitude and pressure to $\mathrm{BC}$ (first row), $\mathrm{SO}_{4}$ (second row), and $\mathrm{SO}_{4}$-induced SST perturbation ( $\mathrm{SO}_{4} \_\mathrm{SST}$ ) (third row). The left and right columns are the DJF and JJA averages, respectively. Note that the color scales for $\mathrm{SO}_{4}$ and $\mathrm{SO}_{4} \mathrm{SST}$ are reversed.

spheric forcing, is strikingly small (except in summer polar regions where air temperature above sea ice is free to change), despite aerosol indirect forcing through fast adjustment of clouds being allowed. The $\mathrm{SO}_{4}$ slow response in winter features a narrow maximum around $30^{\circ} \mathrm{N}$, and the summer mid-latitude response is weaker and extends into the upper tropics. Therefore, the slow component of the response due to SST change is entirely responsible for the $\mathrm{SO}_{4}$ deep atmospheric response and partially responsible for the $\mathrm{BC}$ response.

The dominant role of SST in causing the deep atmospheric response is further confirmed by a set of perturbed-SST experiments, in which the zonal mean SST change in the full $\mathrm{SO}_{4}$ simulation (Fig. $\mathrm{S} 1$ ) is applied to the atmospheric-only model, but with no radiative forcing. The model response to the perturbed SST (third row of Fig. 2) is remarkably similar to the $\mathrm{SO}_{4}$ slow response (Fig. 3), explaining a large fraction of the total response (second row of Fig. 2). The boundary layer air temperature (below $850 \mathrm{mb}$ ) is closely tied to the underlying SST because of turbulent mixing, while at the mid-latitudes, the free atmospheric temperature is not tied to the SST because the atmosphere is stably stratified. However, 


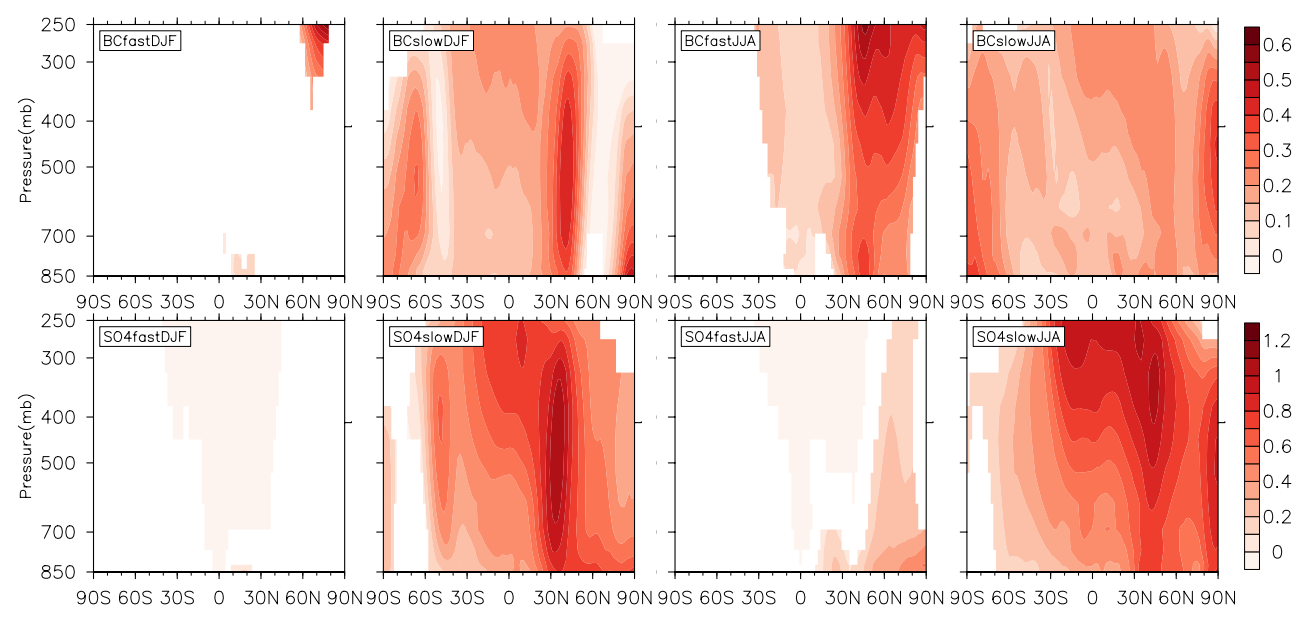

Figure 3. Similar to Fig. 2, but for fast (first and third columns) and slow components (second and fourth columns) of temperature response (in ${ }^{\circ} \mathrm{C}$ ). The fast component is calculated by running the atmospheric-only (fixed SST) simulation with perturbed atmospheric compositions, while the slow component is the difference between the total (Fig. 2) and fast components. The color scale for $\mathrm{SO}_{4}$ is reversed.

changes in the SST may affect the free troposphere through the changes in tropical circulations and mid-latitude eddy, which we explore next.

\section{Understanding zonal mean circulation changes}

Figure 4 shows the circulation responses to aerosols in terms of meridional overturning stream function (positive values indicate clockwise circulation) and zonal averaged zonal wind (positive values indicate westerly winds). Note that the responses of $\mathrm{SO}_{4}$ and $\mathrm{BC}$ are similar in space but of opposite signs. $\mathrm{SO}_{4}$ cooling in the $\mathrm{NH}$ induces an anomalous Hadley cell that rises in the $\mathrm{SH}$ and sinks in the $\mathrm{NH}$ (also shown in Ocko et al., 2014). The atmospheric model forced by $\mathrm{SO}_{4}$-induced SST change largely reproduces the Hadley cell response (Fig. 4, bottom left), highlighting the importance of the inter-hemispheric SST gradient. Consistent with the Hadley cell response, the $\mathrm{NH}$ jet stream shifts equatorward in response to $\mathrm{SO}_{4}$, and vice versa to $\mathrm{BC}$. Following the thermal wind relationship (the maximum temperature gradient sets the maximum zonal wind), the equatorward shift of westerly winds must be accompanied by a deep cooling structure (Figs. 1 and 2).

The color scale for the $\mathrm{SO}_{4}$ response in Fig. 4 is not reversed as in previous temperature figures, in order to depict the real direction of circulation change. The magnitude of changes in response to $\mathrm{BC}$ is weaker due to a smaller forcing magnitude (Table $\mathrm{S} 1$ ). In addition, the $\mathrm{SO}_{4}$-induced Hadley cell change is inter-hemispheric across the Equator, while the BC-induced Hadley cell change appears more confined to the NH. The same for the jet stream shift. This is probably because of the geographic difference in $\mathrm{BC}$ and $\mathrm{SO}_{4}$ forcing (amid both are stronger in $\mathrm{NH}$ than $\mathrm{SH}$ ), which may influence the Pacific and Atlantic branches of jets differently.
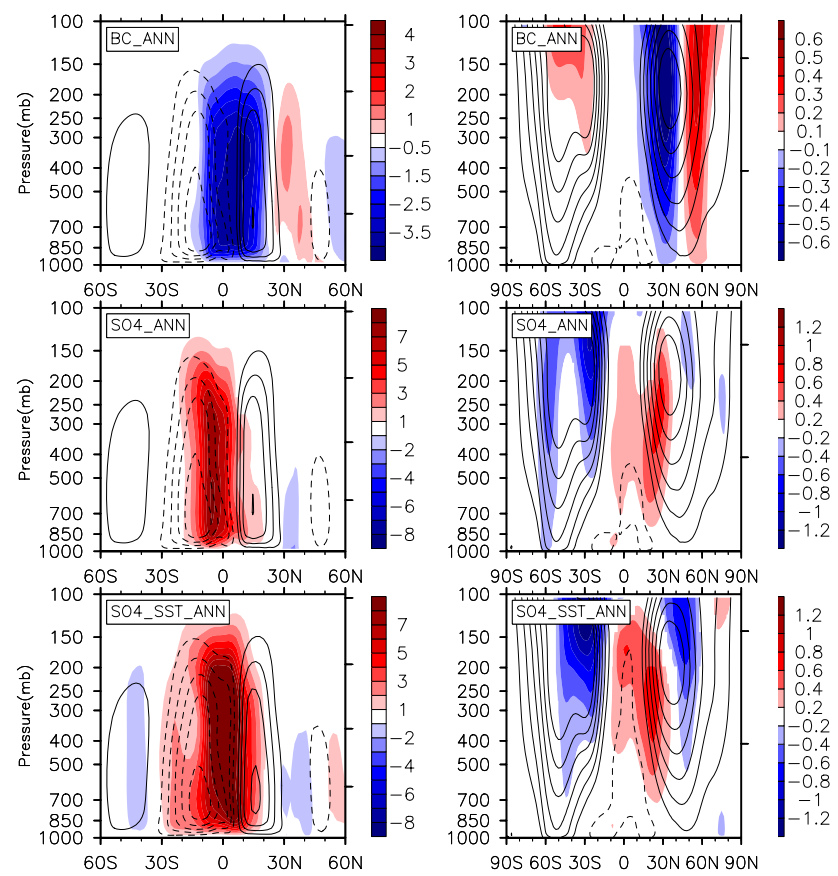

Figure 4. (left) Zonal mean meridional stream function change $\left(10^{9} \mathrm{~kg} \mathrm{~s}^{-1}\right)$, in response to $\mathrm{BC}$ (first row), $\mathrm{SO}_{4}$ (second row), and $\mathrm{SO}_{4}$-induced SST perturbation ( $\mathrm{SO}_{4} \_\mathrm{SST}$ ) (third row). The climatological stream function is shown in contour lines with an interval of 40. The negative values (blue shading and dashed lines) of the stream function indicate that the meridional flow is counterclockwise. (right) Zonal mean zonal wind $(U)$ change under various cases. The climatological jet stream is around 30 to $60^{\circ} \mathrm{N}$ at $250 \mathrm{mb}$ (line contours). Under $\mathrm{SO}_{4}$ forcing, the $\mathrm{NH}$ jet stream shifts significantly equatorward. 


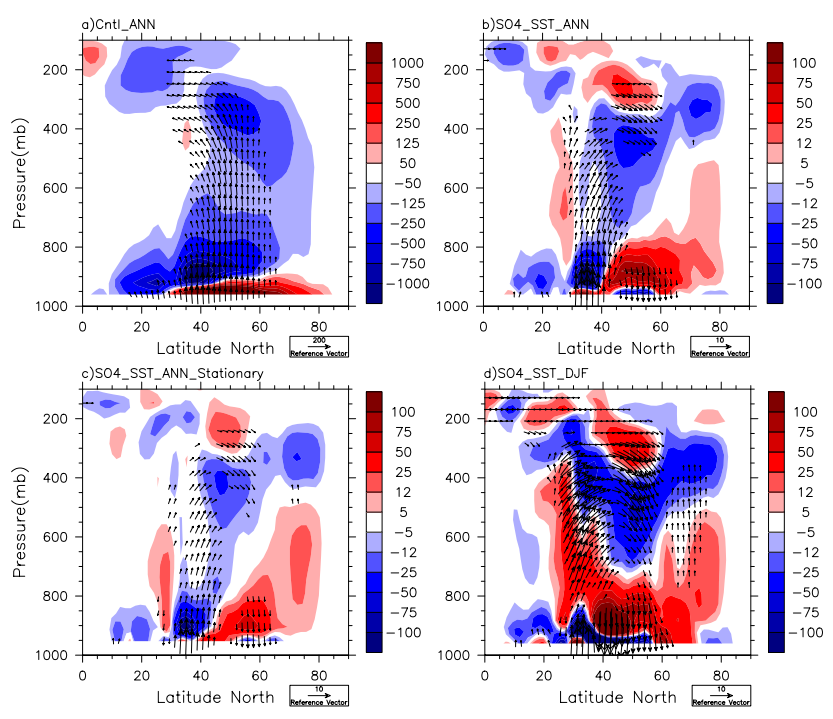

Figure 5. The Eliassen-Palm (EP) flux (vector) and its divergence (contour). (a) The climatology. (b) The change due to $\mathrm{SO}_{4}$-induced SST perturbation $\left(\mathrm{SO}_{4} \_\mathrm{SST}\right)$. The convergence (blue) and divergence (red) of the EP flux correspond to a deceleration and acceleration of the westerly mean flow, respectively. (c) Contributions of the stationary eddy to the change shown in (b). This was calculated using a 10-day average, instead of a daily average. Transient eddies are the difference between the total and stationary contribution (not shown). (d) NH winter (DJF) average, not the annual average shown (b). Note that the color scale and reference vectors are different across the panels.

Eddy fluxes that transport heat and momentum in meridional directions are instrumental in maintaining the climatological mid-latitude jets. Here we use the Eliassen-Palm (EP) flux to diagnose how eddy flux adjustment in response to aerosols leads to changes of zonal winds. The EP flux vector, with its vertical component depicting the meridional heat flux and its meridional component depicting the equatorward meridional momentum flux, is calculated using 10-year daily data from the control and the perturbed $\mathrm{SO}_{4}$ SST simulations following Holton (2004).

The NH annual mean EP flux and its divergence (in contour) are shown in Fig. 5a. Over extratropical atmosphere, EP flux convergence (negative value) suggests that meridional heat eddy flux (the vertical component of EP flux) acts to slow the westerly wind aloft (Holton, 2004). However, the strong equatorward wave propagation in the mid-latitude troposphere (meridional component of EP flux) is acting to extract momentum from the tropics to the mid-latitude, therefore maintaining the westerly wind at $40-60^{\circ} \mathrm{N}$.

Under the $\mathrm{SO}_{4}$-induced SST perturbation, the EP flux change is found to be strongest at the NH mid-latitudes 30$40^{\circ} \mathrm{N}$, equatorward side of its climatology (Fig. 5b). Poleward EP flux anomalies reduce the climatological equatorward wave propagation. In the middle troposphere (400$800 \mathrm{mb}$ ), EP flux convergence (blue) decelerates the verti- cally average westerly wind at $50-60^{\circ} \mathrm{N}$, while EP flux divergence (red) tends to accelerate the westerly wind at 30 $40^{\circ} \mathrm{N}$. Therefore, westerly winds shift equatorward in response to $\mathrm{SO}_{4}$ (Fig. 4). Of the total eddy flux, stationary eddies contribute about $60 \%$ (Fig. 5c), with the rest coming from transient eddies. The EP flux change occurs predominately during the $\mathrm{NH}$ winter, because the background midlatitude wave activity is stronger. This is shown by the larger vectors in Fig. 5d and stronger EP flux divergence (red) at $30-40^{\circ} \mathrm{N}$.

The change in EP flux is consistent with that in the stationary wave refractive index as wave propagation is mainly from a high refractive index region to a low refractive index region (Held and Hou, 1980; Fig. S2). The quasi-geostrophic refractive index and its change under SST perturbation were calculated following Limpasuvan and Hartmann (2000). In the climatology (Fig. S2a), the high refractive index is located at the mid and high latitudes, and the tropics are mainly occupied by a smaller refractive index, facilitating the equatorward propagation of mid-latitude wave activities (Fig. 5a, also seen in Sun et al., 2013). The refractive index negative anomaly due to perturbed $\mathrm{SO}_{4}$ SST is mainly found in the $\mathrm{NH}$ mid-latitude regions (Fig. S2b), which causes the reduction of wave propagation to the Equator (Fig. 5b).

The above diagnosis explains the $\mathrm{SO}_{4}$-induced deep tropospheric cooling and associated equatorward shift of the westerly jet at the NH mid-latitudes. Firstly, the intensified NH Hadley cell accelerates the upper tropospheric westerly jets in the subtropics. Secondly, the EP flux divergence accelerates the westerly jet on the equatorward flank of the mean Hadley cell, while the jet is decelerated on the poleward flank due to EP flux convergence. Both the Hadley and eddy adjustments are anchored by the SST change with strong meridional gradients. Aqua-planet model experiments exploring the response to an idealized mid-latitude heating (Ceppi et al., 2013) supported our arguments here about the coupled adjustments of the Hadley circulation and mid-latitude jets to realistic aerosol forcing.

\section{Conclusions}

Our results show that, despite the fundamental difference in forcing structure, $\mathrm{BC}$ and $\mathrm{SO}_{4}$ share common atmospheric response patterns. The common response is mediated by the ocean through sea-surface temperature gradient, and is insensitive to microphysical representations of aerosols. This highlights the importance of ocean-atmosphere interactions in shaping large-scale patterns of climate response (Xie et al., 2010), a process overlooked so far in aerosol-climate connection.

The deep mid-latitude warming in response to $\mathrm{BC}$ contributes to the retreat of mountain glaciers in the $\mathrm{NH}$ nearanthropogenic BC emissions including the Alps (Painter et al., 2013) and the Himalayas. Although the cooling effect on 
the free troposphere is rarely discussed, $\mathrm{SO}_{4}$ aerosols may have mitigated glacier retreats elsewhere in the past. Into the future, declining $\mathrm{SO}_{4}$ aerosols may lead to an elevated atmospheric warming and pose a threat to mountain snow packs. This implies that more stringent controls on BC and GHGs are needed to mitigate the snow pack retreat.

The tropospheric temperature and circulation response to $\mathrm{SO}_{4}$ is also found in the twentieth century transient simulation (Fig. S3) and the twenty-first century multi-model projections (Rotstayn et al., 2014). This suggests that the deep temperature structure at the mid-latitudes is a robust feature of aerosol-induced climate change, probably insensitive to model sub-grid physics. The dynamic response involving the inter-hemispheric Hadley circulation is weak in the case of $\mathrm{CO}_{2}$ and presumably other hemispherically symmetrical forcing (such as solar and volcanic activities).

The importance of the SST pattern has been noted previously (Ramanathan et al., 2005; Xu and Ramanathan, 2010; Friedman et al., 2013; Xie et al., 2013), and our study reveals a fundamental difference in the mid-latitude atmospheric responses to $\mathrm{CO}_{2}$ and aerosol forcing. This difference can be exploited to improve the detection and attribution of climate change (Lu et al., 2008; Santer et al., 2013). Because aerosol forcing involves stronger mid-latitude storm track adjustments, our result also has implications for the attribution and projection of extreme events (e.g., blockings).

\section{The Supplement related to this article is available online at doi:10.5194/acp-15-5827-2015-supplement.}

Acknowledgements. The authors wish to thank I. Held, P. Ceppi, and L. Sun for discussions, and J. Barsugli for sharing codes for EP flux. Y. Xu is supported by the Regional and Global Climate Modeling Program (RGCM) of the US Department of Energy's Office of Science (BER, DE-FC02-97ER62402) and the National Center for Atmospheric Research (NCAR) Advanced Study Programme (ASP) postdoctoral fellowship; and S. P. Xie by the National Science Foundation (NSF). NCAR is funded by the NSF.

Edited by: J. P. Huang

\section{References}

Allen, R. J., Sherwood, S. C., Norris, J. R., and Zender, C. S.: Recent Northern Hemisphere tropical expansion primarily driven by black carbon and tropospheric ozone, Nature, 485, 350-354, 2012.

Bollasina, M. A., Ming, Y., and Ramaswamy, V.: Anthropogenic aerosols and the weakening of the South Asian summer monsoon, Science, 334, 502-505, 2011.

Bond, T. C., Doherty, S. J., Fahey, D. W., Forster, P. M., Berntsen, T., Deangelo, B. J., Flanner, M. G., Ghan, S., Kärcher, B., Koch,
D., Kinne, S., Kondo, Y., Quinn, P. K., Sarofim, M. C., Schultz, M. G., Schulz, M., Venkataraman, C., Zhang, H., Zhang, S., Bellouin, N., Guttikunda, S. K., Hopke, P. K., Jacobson, M. Z., Kaiser, J. W., Klimont, Z., Lohmann, U., Schwarz, J. P., Shindell, D., Storelvmo, T., Warren, S. G., and Zender, C. S.: Bounding the role of black carbon in the climate system: A scientific assessment, J. Geophys. Res.-Atmos., 118, 5380-5552, 2013.

Ceppi, P., Hwang, Y.-T., Liu, X., Frierson, D. M. W., and Hartmann, D. L.: The relationship between the ITCZ and the Southern Hemispheric eddy-driven jet, J. Geophys. Res.-Atmos., 118, 5136-5146, 2013.

Flanner, M. G., Zender, C. S., Randerson, J. T., and Rasch, P. J.: Present-day climate forcing and response from black carbon in snow, J. Geophys. Res.-Atmos., 112, D11202, doi:10.1029/2006JD008003, 2007.

Friedman, A. R., Hwang, Y.-T., Chiang, J. C. H., and Frierson, D. M. W.: Interhemispheric temperature asymmetry over the 20th century and in future projections, J. Climate, 26, 5419-5433, 2013.

Ganguly, D., Rasch, P. J., Wang, H., and Yoon, J.: Fast and slow responses of the South Asian monsoon system to anthropogenic aerosols, Geophys. Res. Lett., 39, L18804, doi:10.1029/2012GL053043, 2012.

Gettelman, A., Liu, X., Ghan, S. J., Morrison, H., Park, S., Conley, A. J., Klein, S. A., Boyle, J., Mitchell, D. L., and Li, J.-L. F.: Global simulations of ice nucleation and ice supersaturation with an improved cloud scheme in the Community Atmosphere Model, J. Geophys. Res.-Atmos., 115, D18216, doi:10.1029/2009JD013797, 2010.

Held, I. M. and Hou, A. Y.: Nonlinear axially symmetric circulations in a nearly inviscid atmosphere, J. Atmos. Sci., 37, 515533, 1980.

Holton, J.: An Introduction to Dynamic Meteorology, 4th Edn., Elsevier Academic Press, San Diego, 535 pp., 2004.

Huang, J., Fu, Q., Zhang, W., Wang, X., Zhang, R., Ye, H., and Warren, S.: Dust and black carbon in seasonal snow across northern China, B. Am. Meteorol. Soc., 92, 175-181, doi:10.1175/2010BAMS3064.1, 2011.

Hwang, Y.-T., Frierson, D. M. W., and Kang, S. M.: Anthropogenic sulfate aerosol and the southward shift of tropical precipitation in the late 20th century, Geophys. Res. Lett., 40, 2845-2850, 2013.

Koch, D. and Del Genio, A. D.: Black carbon semi-direct effects on cloud cover: review and synthesis, Atmos. Chem. Phys., 10, 7685-7696, doi:10.5194/acp-10-7685-2010, 2010.

Lamarque, J.-F., Bond, T. C., Eyring, V., Granier, C., Heil, A., Klimont, Z., Lee, D., Liousse, C., Mieville, A., Owen, B., Schultz, M. G., Shindell, D., Smith, S. J., Stehfest, E., Van Aardenne, J., Cooper, O. R., Kainuma, M., Mahowald, N., McConnell, J. R., Naik, V., Riahi, K., and van Vuuren, D. P.: Historical (1850-2000) gridded anthropogenic and biomass burning emissions of reactive gases and aerosols: methodology and application, Atmos. Chem. Phys., 10, 7017-7039, doi:10.5194/acp10-7017-2010, 2010.

Lau, K. M., Kim, M. K., and Kim, K. M.: Asian summer monsoon anomalies induced by aerosol direct forcing: the role of the Tibetan Plateau, Clim. Dynam., 26, 855-864, 2006.

Levy, H., Horowitz, L. W., Schwarzkopf, M. D., Ming, Y., Golaz, J.-C., Naik, V., and Ramaswamy, V.: The roles of aerosol direct 
and indirect effects in past and future climate change, J. Geophys. Res. Atmos., 118, 4521-4532, 2013.

Limpasuvan, V. and Hartmann, D.: Wave-maintained annular modes of climate variability, J. Climate, 13, 4414-4429, 2000.

Liu, X., Easter, R. C., Ghan, S. J., Zaveri, R., Rasch, P., Shi, X., Lamarque, J.-F., Gettelman, A., Morrison, H., Vitt, F., Conley, A., Park, S., Neale, R., Hannay, C., Ekman, A. M. L., Hess, P., Mahowald, N., Collins, W., Iacono, M. J., Bretherton, C. S., Flanner, M. G., and Mitchell, D.: Toward a minimal representation of aerosols in climate models: description and evaluation in the Community Atmosphere Model CAM5, Geosci. Model Dev., 5, 709-739, doi:10.5194/gmd-5-709-2012, 2012.

Long, S.-M., Xie, S.-P., Zheng, X.-T., and Liu, Q.: Fast and Slow Responses to Global Warming: Sea Surface Temperature and Precipitation Patterns, J. Climate, 27, 285-299, doi:10.1175/JCLI-D-13-00297.1, 2014.

Lu, J., Chen, G., and Frierson, D. M. W.: Response of the Zonal Mean Atmospheric Circulation to El Niño versus Global Warming, J. Climate, 21, 5835-5851, doi:10.1175/2008JCLI2200.1, 2008.

Manabe, S. and Wetherald, R. T.: The effects of doubling the $\mathrm{CO}_{2}$ concentration on the climate of a general circulation model, $\mathrm{J}$. Atmos. Sci., 32, 3-15, 1975.

Meehl, G. A., Arblaster, J. M., and Collins, W. D.: Effects of black carbon aerosols on the Indian Monsoon, J. Climate, 21, 28692882, 2008 .

Meehl, G. A., Washington, W. M., Arblaster, J. M., Hu, A., Teng, H., Kay, J. E., Gettelman, A., Lawrence, D. M., Sanderson, B. M., and Strand, W. G.: Climate Change Projections in CESM1(CAM5) Compared to CCSM4, J. Climate, 26, 62876308, 2013.

Ocko, I. B., Ramaswamy, V., and Ming, Y.: Contrasting climate responses to the scattering and absorbing features of anthropogenic aerosol forcings, J. Climate, 27, 5329-5345, 2014.

Painter, T. H., Flanner, M. G., Kaser, G., Marzeion, B., VanCuren, R. A., and Abdalati, W.: End of the Little Ice Age in the Alps forced by industrial black carbon, P. Natl. Acad. Sci. USA, 110, 15216-15221, 2013.

Ramanathan, V. and Feng, Y.: On avoiding dangerous anthropogenic interference with the climate system: formidable challenges ahead, P. Natl. Acad. Sci. USA, 105, 14245-14250, 2008.

Ramanathan, V., Chung, C., Kim, D., Bettge, T., Buja, L., Kiehl, J. T., Washington, W. M., Fu, Q., Sikka, D. R., and Wild, M.: Atmospheric brown clouds: Impacts on South Asian climate and hydrological cycle, P. Natl. Acad. Sci. USA, 102, 5326-5333, 2005.
Rosenfeld, D., Wood, R., Donner, L., and Sherwood, S.: Aerosol Cloud-Mediated Radiative Forcing: Highly Uncertain and Opposite Effects from Shallow and Deep Clouds, in: Climate Science for Serving Society, edited by: Asrar, G. R. and Hurrell, J. W., 105-149, Springer, the Netherlands, 2013.

Rotstayn, L. D., Plymin, E. L., Collier, M. A., Boucher, O., Dufresne, J.-L., Luo, J.-J., von Salzen, K., Jeffrey, S. J., Foujols, M.-A., Ming, Y., and Horowitz, L. W.: Declining Aerosols in CMIP5 Projections: Effects on Atmospheric Temperature Structure and Midlatitude Jets, J. Climate, 27, 6960-6977, 2014.

Santer, B. D., Painter, J. F., Mears, C. A., Doutriaux, C., Caldwell, P., Arblaster, J. M., Cameron-Smith, P. J., Gillett, N. P., Gleckler, P. J., Lanzante, J., Perlwitz, J., Solomon, S., Stott, P. A., Taylor, K. E., Terray, L., Thorne, P. W., Wehner, M. F., Wentz, F. J., Wigley, T. M. L., Wilcox, L. J., and Zou, C.-Z.: Identifying human influences on atmospheric temperature, P. Natl. Acad. Sci. USA, 110, 26-33, 2013.

Shindell, D. T., Voulgarakis, A., Faluvegi, G., and Milly, G.: Precipitation response to regional radiative forcing, Atmos. Chem. Phys., 12, 6969-6982, doi:10.5194/acp-12-6969-2012, 2012.

Smith, S. J., van Aardenne, J., Klimont, Z., Andres, R. J., Volke, A., and Delgado Arias, S.: Anthropogenic sulfur dioxide emissions: 1850-2005, Atmos. Chem. Phys., 11, 1101-1116, doi:10.5194/acp-11-1101-2011, 2011.

Sun, L., Chen, G., and Lu, J.: Sensitivities and mechanisms of the zonal mean atmospheric circulation response to tropical warming, J. Atmos. Sci., 70, 2487-2504, 2013.

Vinoj, V., Rasch, P. J., Wang, H., Yoon, J.-H., Ma, P.-L., Landu, K., and Singh, B.: Short-term modulation of Indian summer monsoon rainfall by West Asian dust, Nat. Geosci, 7, 308-313, 2014.

Xie, S.-P., Deser, C., Vecchi, G. A., Ma, J., Teng, H., and Wittenberg, A. T.: Global Warming Pattern Formation: Sea Surface Temperature and Rainfall, J. Climate, 23, 966-986, doi:10.1175/2009JCLI3329.1, 2010.

Xie, S., Lu, B., and Xiang, B.: Similar spatial patterns of climate responses to aerosol and greenhouse gas changes, Nat. Geosci., 6, 828-832, 2013.

$\mathrm{Xu}$, Y. and Ramanathan, V.: Latitudinally asymmetric response of global surface temperature: implications for regional climate change, Geophys. Res. Lett., 39, L13706, doi:10.1029/2012GL052116, 2012.

Xu, Y., Bahadur, R., Zhao, C., and Ruby Leung, L.: Estimating the radiative forcing of carbonaceous aerosols over California based on satellite and ground observations, J. Geophys. Res.-Atmos., 118, 11148-11160, 2013. 